\title{
INCORPORATION OF LABELLED NUCLEOSIDES IN VITRO BY RABBIT AND MINK BLASTOCYSTS IN THE PRESENCE OF BLASTOKININ OR SERUM
}

\author{
BELA J. GULYAS, * JOSEPH C. DANIEL, JR AND \\ R. S. KRISHNAN† \\ University of Colorado Department of Molecular, Cellular and \\ Developmental Biology, Boulder, Colorado 80302
}

(Received 6th September 1968)

\begin{abstract}
Summary. The effects of the rabbit uterine fluid component, blastokinin (BKN), and rabbit serum on nucleic acid synthesis in rabbit and mink blastocysts were examined. $\left[{ }^{3} \mathrm{H}\right]$ Thymidine incorporation was not enhanced by BKN in rabbit embryos explanted on the 3 rd to 5 th days post coitum, but thymidine uptake was somewhat greater in 4- and 5-day blastocysts in serum-containing medium than in the controls in defined medium. $\left[{ }^{3} \mathrm{H}\right]$ Uridine incorporation was inhibited slightly by serum and significantly stimulated by BKN in 5-day rabbit blastocysts, but not in younger ones. Rabbit serum inhibited uridine uptake in mink blastocysts, while BKN had no effect.
\end{abstract}

\section{INTRODUCTION}

A number of investigators have predicted a dependent relationship, other than nutritional, between the rapidly developing embryo and the maternal milieu (Hammond, 1928; Adams, 1965; Kirby, 1965; Weitlauf \& Greenwald, 1965, 1967). The discovery of the uterine fluid factor, blastokinin (BKN), and its rôle in regulating rabbit blastocyst development (Krishnan \& Daniel, 1967) demonstrates such a relationship. The work reported here was designed to study the influence of BKN on nucleic acid synthesis in 'active' rabbit and 'dormant' mink blastocysts. Because Daniel (1965) has shown that rabbit blastocysts grow better when F10 medium is supplemented with maternal serum, tests were also carried out to determine the effect of serum on nucleic acid synthesis in rabbit and mink blastocysts.

\section{MATERIALS AND METHODS}

Three-day rabbit morulae, 4- and 5-day rabbit blastocysts and 15-, 20- and 25-day mink blastocysts were used to study the effects of BKN with or without serum on nucleic acid synthesis in the embryos of mammals with and without delayed implantation.

* Present address: University of Washington, Medical Center, Department of Biological Structure, Seattle, Washington 98105.

+ Present address: Department of Biochemistry, Colorado State University, Fort Collins, Colorado 80521 . 
Embryos were pooled from at least two animals and were divided into experimental groups so that their sizes varied minimally in a given set of experiments, although they varied from one repeat to the next.

The blastocysts were pre-cultured (Daniel, 1965) for $2 \mathrm{hr}$ in $0.5 \mathrm{ml}$ of F10 medium (Ham, 1963), each culture dish containing one or two blastocysts. During this time, the BKN which is present in the blastocoele of the rabbit blastocyst (Krishnan \& Daniel, 1967) is thought to be diluted by a factor of 300 to 400 . At the end of the 2-hr period, the blastocysts were divided into four groups and each group cultured in one of the four media listed below:

(A) F10 (control)

(B) FI0 plus BKN $(0 \cdot 2 \mathrm{mg} / \mathrm{ml})$

(C) F10 plus lyophilized rabbit serum $(5 \mathrm{mg} / \mathrm{ml})$

(D) F10 plus BKN plus serum

The BKN used was prepared according to procedures described earlier (Krishnan \& Daniel, 1967). The culture medium in Groups A to D contained either $20 \mu \mathrm{Ci} / \mathrm{ml}$ of $\left[{ }^{3} \mathrm{H}\right]$ thymidine-meth (specific activity $15.6 \mathrm{Ci} / \mathrm{m}$-mole) or $\left[5-{ }^{3} \mathrm{H}\right]$ uridine (specific activity $19.5 \mathrm{Ci} / \mathrm{m}$-mole) obtained from New England Nuclear Corporation. The blastocysts were labelled for $2 \mathrm{hr}$. After the labelling period, the blastocysts were incubated for 2 more hours in F10 medium containing either pulse concentration of unlabelled thymidine or ten times the pulse concentration of uridine as the case may be.

At the end of the chase period, the blastocysts were transferred into individual test tubes with a medium containing $1 \%$ pronase $(\mathrm{Mintz}, 1962)$ to remove the zonae pellucidae. This procedure requires less than a minute at room temperature. All enzymatic reactions were terminated by the addition of $0.5 \mathrm{ml}$ freshly mixed sodium dodecyl sulphate (SDS) and urea at a final concentration of $1 \%$ SDS and 5 m-urea. The blastocysts were left in the SDS-urea at room temperature for $30 \mathrm{~min}$ to assure complete destruction of the cells.

The samples were precipitated with $1 \mathrm{ml}$ cold $\left(0\right.$ to $\left.4^{\circ} \mathrm{C}\right) \mathrm{TCA}$ at $10 \%$ final concentration and the precipitate was filtered on to Whatman glass paper filter discs $(2.4 \mathrm{~cm}$ in diameter). The test tubes were rinsed three times with a total of $10 \mathrm{ml}$ cold $10 \% \mathrm{TCA}$ and the filter discs were washed with the corresponding rinses. With every set of experiments, a $0.1-\mathrm{ml}$ aliquot of the 'hot' medium was placed on a filter paper disc and processed as described. The counts of these filters were used for background counts which were subtracted from the experimental counts in each case.

Scintillation vials contained $12 \mathrm{ml}$ scintillation fluid. A stock solution was prepared by dissoving $1.25 \mathrm{~g}$ POPOP and $62.5 \mathrm{~g}$ PPO (Arapahoe Chemicals) in 2 litres of toluene (Matheson, Goleman \& Bell). Four ml of this stock solution were mixed with $21 \mathrm{ml}$ toluene for counting purposes. The samples were counted in a Beckman LS-133 liquid scintillation spectrometer at ambient temperature.

\section{RESULTS}

Thymidine incorporation in the presence of $B K \mathcal{N}$

The measurements of $\left[{ }^{3} \mathrm{H}\right]$ thymidine incorporation by 3-, 4- and 5-day rabbit embryos are given in Table 1 . Since the analysis of variance (Steel \& 
Torrie, 1960) was near the significant level for the 4-day blastocysts and was significant for the 5-day blastocysts $(P<0 \cdot 01)$, Duncan's multiple range test (Steel \& Torrie, 1960) was applied to compare every treatment mean with every other treatment mean.

In the presence of $\mathrm{BKN},\left[{ }^{3} \mathrm{H}\right]$ thymidine incorporation did not increase or decrease in the three age groups of rabbit embryos. In the 4- and 5-day blastocysts, the highest incorporation was in the presence of rabbit serum, the results being at the border-line of significance.

\section{TABLE 1}

$\left[{ }^{3}\right.$ H]THYMIDINE INCORPORATION INTO RABBIT EMBRYOS

\begin{tabular}{c|c|c|c|c}
\hline \multirow{2}{*}{$\begin{array}{c}\text { Age of } \\
\text { embryos } \\
\text { (post coitum })\end{array}$} & \multicolumn{4}{|c}{ Counts/min*/embryo (Mean $\dagger \pm$ S.E.) } \\
\cline { 2 - 5 } & $\begin{array}{c}F 10(\text { control }) \\
(A)\end{array}$ & $\begin{array}{c}B K \mathcal{N} \\
(B)\end{array}$ & $\begin{array}{c}\text { Serum } \\
(C)\end{array}$ & $\begin{array}{c}B K \mathcal{N} \text { and serum } \\
(D)\end{array}$ \\
\hline 3-day & $64 \pm 20$ & $43 \pm 2 \cdot 3$ & $43 \pm 13$ & $33 \pm 32$ \\
4-day & $42 \pm 3$ & $55 \pm 12$ & $89 \pm 18$ & $82 \pm 19$ \\
5-day & $355 \pm 177$ & $166 \pm 28$ & $452 \pm 299$ & $386 \pm 145$ \\
\hline
\end{tabular}

* External Standard Ratios 0.751 \pm 0.003 .

$\dagger$ All means are average of four experiments.

TABLE 2

$\left[{ }^{3} \mathrm{H}\right]$ URIDINE INCORPORATION INTO RABBIT EMBRYOS

\begin{tabular}{|c|c|c|c|c|}
\hline \multirow{2}{*}{$\begin{array}{c}\text { Age of } \\
\text { embryos } \\
\text { (post coitum) }\end{array}$} & \multicolumn{4}{|c|}{ Counts/min*/embryo (Mean† $\pm S . E)}$. \\
\hline & $\begin{array}{c}F 10(\text { control }) \\
(A)\end{array}$ & $\underset{(B)}{B K \mathcal{N}}$ & $\begin{array}{l}\text { Serum } \\
(C)\end{array}$ & $\begin{array}{l}B K \mathcal{N} \text { and serum } \\
(D)\end{array}$ \\
\hline $\begin{array}{l}\text { 3-day } \\
\text { 4-day } \\
\text { 5-day }\end{array}$ & $\begin{array}{l}1292 \pm 261 \\
2496 \pm 216 \\
5544 \pm 323\end{array}$ & $\begin{array}{r}951 \pm 131 \\
2930 \pm 194 \\
7760 \pm 304\end{array}$ & $\begin{array}{l}1549 \pm 214 \\
2640 \pm 165 \\
3397 \pm 266\end{array}$ & $\begin{array}{r}655 \pm 221 \\
3239 \pm 186 \\
4374 \pm 223\end{array}$ \\
\hline
\end{tabular}

* External Standard Ratios 0.751 \pm 0.003 .

$\dagger$ All means are average of five experiments.

The combination of BKN and serum gave the lowest counts in the 3-day morulae and somewhat higher than the control in the 4- and 5-day blastocysts. It is concluded that $\left[{ }^{3} \mathrm{H}\right]$ thymidine incorporation was not affected in the 3-, 4- and 5-day rabbit embryos by BKN or serum under the tested experimental conditions.

The results of the experiments on $\left[{ }^{3} \mathrm{H}\right]$ uridine incorporation by rabbit embryos are presented in Table 2 . The analysis of variance was significant in all three groups $(P<0.005)$; therefore, the treatment means were analysed by Duncan's test.

In the presence of $\mathrm{BKN}$, 3-day rabbit morulae showed lower uridine incorporation than the controls, but by Day 4 the incorporation was higher than in the controls. The counts per embryo in BKN were not significantly different from the controls in either of these two age groups. Uridine incorporation was 
increased substantially $(P<0.05)$ in the 5 -day blastocysts in the presence of BKN.

Uridine incorporation with serum is somewhat higher than the control in both the 3-day morulae and the 4-day blastocysts, but is considerably lower $(P>0.05)$ in the 5-day blastocysts. The blastocysts grown in serum-containing medium resembled normal blastocysts more than those from the other experimental groups in that they were never observed to collapse or shrink away from the zona pellucida during the course of the experiments.

The combination of BKN and serum resulted in the lowest rate of $\left[{ }^{3} \mathrm{H}\right]$ uridine incorporation in the 3-day morulae, going from significantly lower $(P>0.05)$ counts in the morulae to significantly higher $(P<0.05)$ in the 4-day blastocysts

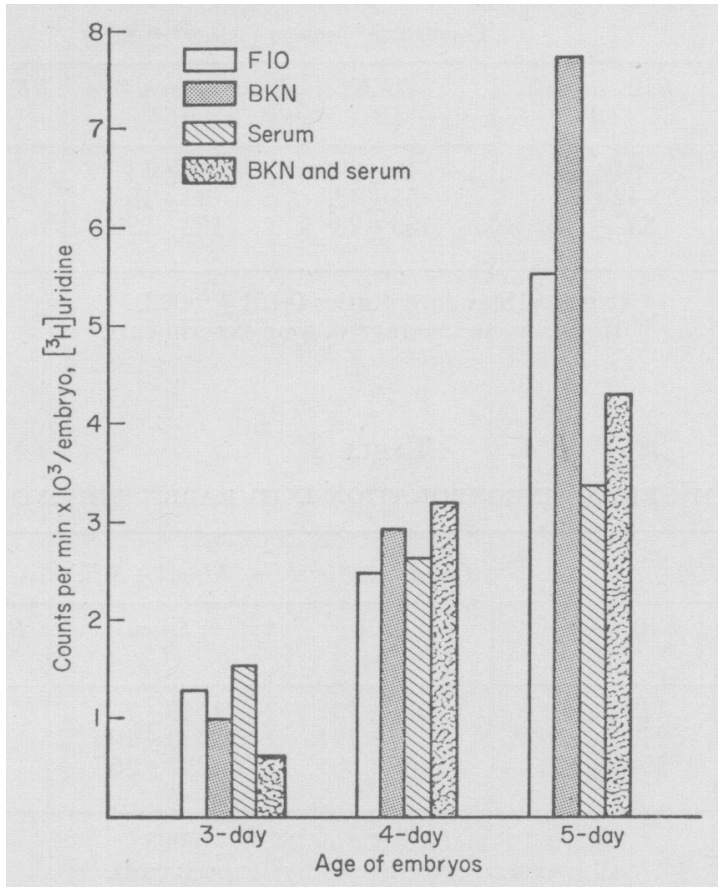

TEXT-FIG. 1. $\left[{ }^{3} \mathrm{H}\right]$ Uridine incorporation into rabbit morulae and blastocysts in F10 alone and when supplemented with blastokinin and/or serum. Incorporation was measured by liquid scintillation counting.

compared to the controls. In the 5-day blastocysts in BKN and serum, uptake of uridine was again below the controls $(P>0 \cdot 05)$. A graphic presentation of $\left[{ }^{3} \mathrm{H}\right]$ uridine incorporation into 3-day morulae and 4 - and 5-day blastocysts under the three experimental conditions is shown in Text-fig. 1.

Five-day rabbit blastocysts were cultured in BKN, $\left[{ }^{3} \mathrm{H}\right]$ uridine with the addition of either $2 \mu \mathrm{g} / \mathrm{ml}$ actinomycin D (Merk, Sharp \& Dohme) or $75 \mu \mathrm{g} / \mathrm{ml}$ of puromycin (Sigma) to observe their effect on uridine incorporation. The results of these experiments are given in Table 3. At the end of the 2-hr culturing period, the blastocysts were partially collapsed in both groups and no signs of recovery could be seen in any of these blastocysts at the end of the chase period. 
Uridine incorporation by mink blastocysts

Table 4 shows the results of the studies on $\left[{ }^{3} \mathrm{H}\right]$ uridine incorporation into mink blastocysts. Counts obtained from 15- and 20-day mink blastocysts in diapause cannot be regarded as exceeding the background count. The total level of uridine incorporation is much higher in 25-day blastocysts but the rate is not enhanced by the presence of BKN. On the contrary, rabbit serum and BKN with serum appeared to inhibit uridine incorporation, as shown by Student's test $(P<0 \cdot 05)$.

TABle 3

EFFECTS OF SPECIFIG INHIBITORS ON THE UPTAKE OF $\left[{ }^{3} \mathbf{H}\right]-$ URIDINE BY 5-DAY RABBIT BLASTOCYSTS CULTURED IN FIO AND IN F10 WITH BKN

\begin{tabular}{l|c|c|c}
\hline \multirow{4}{*}{$\begin{array}{c}\text { Culture } \\
\text { medium }\end{array}$} & \multicolumn{3}{|c}{ Counts/min*/embryo \pm S.E. } \\
\cline { 2 - 4 } & Alone $\ddagger$ & $\begin{array}{c}\text { Actinomycin } D \\
(2 \mu g / m l)\end{array}$ & $\begin{array}{c}\text { Puromycin } \\
(75 \mu g / m l)\end{array}$ \\
\hline F10 $\dagger^{\dagger}$ and BKN $\dagger$ & $5544 \pm 323$ & $626 \pm 130$ & $1163 \pm 243$ \\
& $7760 \pm 304$ & $331 \pm 128$ & $1561 \pm 379$ \\
\hline
\end{tabular}

* External Standard Ratios 0.750 \pm 0.003 .

$\dagger$ All means are average of five experiments.

$\ddagger$ From Table 2.

TABLE 4

$\left[{ }^{3} \mathrm{H}\right]$ URIDINE INCORPORATION INTO MINK BLASTOCYSTS

\begin{tabular}{c|c|c|c|c}
\hline \multirow{2}{*}{$\begin{array}{c}\text { Age of } \\
\text { blastocysts } \\
\text { (post coitum) }\end{array}$} & \multicolumn{4}{|c}{ Counts/min*/embryo (Means) } \\
\cline { 2 - 5 } & $F 10$ (control) & $B K \mathcal{N}$ & Serum & BKN and serum \\
\hline 15-day† & 1 & 1 & $0 \cdot 7$ & $0 \cdot 7$ \\
20-day & 8 & $4 \cdot 5$ & $8 \cdot 5$ & $3 \cdot 5$ \\
25-day & 764 & 767 & 500 & 378 \\
\hline
\end{tabular}

* External Standard Ratios 0.750 \pm 0.003 .

$\dagger$ Average of three experiments.

$\$$ Average of two experiments.

\section{DISCUSSION}

Thymidine uptake into rabbit embryos in the presence of $B K \mathcal{N}$ or serum

The first consideration was to determine whether or not BKN promotes blastocyst growth by stimulating further replication of the genetic material. From the results of the present studies, it seems evident that BKN has no stimulatory effect on thymidine incorporation in the 3-, 4- and 5-day rabbit embryos. Although serum appears to provide a more favourable growing condition for the blastocysts than F10 medium alone, it also does not enhance DNA synthesis.

Uridine uptake into rabbit embryos in the presence of $B K \mathcal{N}$

From the results of uridine incorporation by rabbit embryos (Table 2), it is 
suggested that BKN has some stimulatory effect on uridine uptake. Before discussing these results, it is important to remember that the rabbit embryos, especially 4- and 5-day blastocysts, were exposed to BKN in the uterine environment before the experiments. There was no way of eliminating this initial exposure. Embryos were, however, deprived of BKN for $2 \mathrm{hr}$ before the start of the actual experiments and the BKN present in the blastocoele was thought to be diluted 300- to 400-fold in F10 medium. The results of these experiments are a measure of the effect of exogenous BKN on embryos which were deprived of BKN after exposure to it in the uterine horns.

Since 3-day rabbit morulae are generally found at the utero-tubal junction, they have not yet been exposed to the uterine environment, and BKN is only found in minute quantities in the 3-day uterine flushings (Krishnan \& Daniel, 1967). It is unlikely, therefore, that these embryos have been influenced by $\mathrm{BKN}$, and indeed uridine incorporation is not enhanced in the 3-day morulae; on the contrary, it seems to be slightly lower in the presence of BKN. The highest concentration of BKN is found in the 5-day rabbit uterine flushings and, coincidentally, uridine incorporation is greatest in vitro in the 5-day blastocysts (Text-fig. 1).

BKN has been shown to stimulate blastulation and expansion (Krishnan \& Daniel, 1967) and to stimulate $\left[{ }^{3} \mathrm{H}\right]$ uridine incorporation, but there is no evidence to support a causal relation between these two events. Initial blastulation occurs at $3 \frac{1}{2}$ days and maximal stimulation of uridine uptake occurs in the 5-day blastocysts. It was noted earlier, however, that morulae which transformed to blastocysts in vitro in the presence of BKN appeared abnormal (Krishnan \& Daniel, 1967), suggesting that BKN may not be the only factor involved in blastulation.

\section{Inhibition of uridine uptake by actinomycin $D$ or puromycin}

Although there is a $140 \%$ greater uridine uptake in 5-day blastocysts in the presence of BKN compared with the controls in F10 alone, the presence of actinomycin $\mathrm{D}$ in the medium reduces both to approximately the same level. This means a reduction to $11.2 \%$ of the original incorporation in those blastocysts cultured in F10, but a reduction to $4.2 \%$ in those kept in F10 with BKN. Thus the influence of BKN is directly reversed by an inhibitor of DNAdependent RNA synthesis. Puromycin also inhibits uridine uptake by rabbit blastocysts. There is a reduction to 20 to $21 \%$ of the original incorporation for the embryos retained in BKN-supplemented-F10 or in F10 alone. Thus, direct inhibition of protein synthesis limits the incorporation of RNA precursors to the same degree regardless of whether the embryos have been stimulated by BKN or not. Presumably at least one of the protein products normally synthesized by the embryos, for example, RNA polymerase, is essential for further RNA synthesis.

\section{Uridine uptake into rabbit embryos in the presence of serum}

Daniel (1965) reported an increase in the size of rabbit blastocysts when $5 \%$ rabbit serum was added to F10 medium and these observations were confirmed in the present studies. Uridine uptake in medium containing serum, however, is 
nearly the same as in F10 medium alone (Text-fig. 1), for the 3- and 4-day embryos and 5-day blastocysts incorporated less $\left[{ }^{3} \mathrm{H}\right]$ uridine than the controls. The presence of BKN with serum seems to counterbalance some of the serum effects, but uridine incorporation is still below the control level. It is conceivable that the serum contains some component which is harmful to the 5-day rabbit blastocysts, but has little or no effect on the 3-day stages.

\section{Uridine uptake into mink blastocysts with $B K \mathcal{N}$ and/or serum}

Uridine uptake in mink blastocysts measured by liquid scintillation techniques confirmed results of earlier experiments using autoradiography (Gulyas \& Daniel, 1969). Very small quantities of uridine were incorporated into 15and 20-day blastocysts but 25-day mink blastocysts showed active incorporation. The 25-day blastocysts were twice the diameter of the 15- and 20-day blastocysts and, according to Baevsky (1963), should have been initiating implantation. Uridine incorporation was not stimulated by rabbit BKN in any of these embryos, but there may have been some inhibition by serum of the 25-day stages.

Daniel (1967a) could not grow mink blastocysts in vitro when he supplemented Ham's F10 medium with any of the following: 5, 10 and 25\% rabbit serum, rabbit uterine fluid, or blastocoele fluid with $10 \%$ rabbit serum. Apparently, rabbit serum has no components which maintain growth, or may contain components which are detrimental to mink blastocysts and paralyse essential metabolic processes, such as uridine uptake. The inhibitory effect of serum is reciprocal since rabbit blastocysts, at concentrations of $5 \%$ or higher, fail to grow in mink serum (Daniel, 1967a), in fur seal serum or in fur seal serum dialysate (Daniel, 1967b).

The failure of BKN to stimulate these embryos is not surprising, although work in this laboratory showed in vitro that it stimulates the mitotic activity of mink and of some other blastocysts in diapause (Daniel \& Krishnan, in preparation). In those experiments, however, the mitotic index was measured after $24 \mathrm{hr}$ exposure to $\mathrm{BKN}$, whereas, in the present experiments, the uridine incorporation was measured after only 2-hr exposure. Moreover, the BKN used in these experiments came from rabbits and its failure to stimulate RNA synthesis in mink blastocysts may be evidence of some species specificity.

\section{ACKNOWLEDGMENTS}

This research was supported by NIH Fellowship No. 4-F1-GM-32, 621, NSF Grant No. GB 6363, and NIH Grant No. HD-02282.

Research conducted by B. J. Gulyas in partial fulfilment of the requirements for Ph.D. degree at the University of Colorado, Institute for Developmental Biology.

\section{REFERENCES}

ADAms, G. E. (1965) The influence of maternal environment on preimplantation stages of pregnancy in the rabbit. In: Preimplantation Stages of Pregnancy, pp. 345-373. Ciba Foundation Symposium, Eds. G. E. W. Wolstenholme and M. O'Connor. Little, Brown. Boston. 
BAEvsky, U. B. (1963) The effects of embryonic diapause on the nuclei and mitotic activity of mink and rat blastocysts. In: Delayed Implantation, p. 141. Ed. A. C. Enders. University of Chicago Press.

Daniel, J. G., JR (1965) Studies on the growth of 5-day old rabbit blastocysts in vitro. F. Embryol. exp. Morph. 13, 83.

DANiel, J. C., JR (1967a) Studies on growth of the mink blastocyst. 7. Embryol. exp. Morph. 17, 293.

Daniel, J. G., JR (1967b) Preliminary studies on the diapausing blastocyst of the Northern fur seal. $A m$. Zoologist, 7, 75 .

Gulyas, B. J. \& DANIEL, J. C., JR (1969) Incorporation of labeled nucleic acid and protein precursors by diapausing and nondiapausing blastocysts. Biol. Reprod. 1, 11.

HAM, R. G. (1963) An improved nutrient solution for diploid Chinese hamster and human cell lines. Expl Cell Res. 29, 515.

Hammond, J. (1928) Die Kontralle der Fruchtbarkeit bei Tieren. Züchtungskunde, 3, 523.

KIRBY, D. R. S. (1965) The role of uterus in the early stages of mouse development. In: Preimplantation Stages of Pregnancy, pp. 325-339. Ciba Foundation Symposium, Eds. G. E. W. Wolstenholme and M. O'Connor. Little, Brown, Boston.

Krishinan, R. S. \& Daniel, J. C., JR (1967) 'Blastokinin': Inducer and regulator of blastocyst development in the rabbit uterus. Science, N.Y. 158, 490.

Mintz, B. (1962) Experimental study of the developing mammalian egg: Removal of the zona pellucida. Science, $\mathcal{N} . \Upsilon$. 138, 594.

Steel, R. G. D. \& Torrie, J. H. (1960) Principles and procedures of statistics, chap. 9. McGraw-Hill, New York.

Wertlauf, H. M. \& Greenwald, G. S. (1965) A comparison of ${ }^{35} \mathrm{~S}$ methionine incorporation by the blastocysts of normal and delayed implanting mice. F. Reprod. Fert. 10, 203.

Weitlauf, H. M. \& Greenwald, G. S. (1967) A comparison of the in vivo incorporation of ${ }^{35} \mathrm{~S}$ methionine by two-celled mouse eggs and blastocysts. Anat. Rec. 159, 249. 